\title{
Association between Admission Hyperglycemia and Outcome in Acute Ischemic Stroke Cases: an Observational Study
}

\author{
Priyatosh Chandra Das ${ }^{1 *}$, Islam M M ${ }^{1}$, Sarkar $\mathbf{S}^{2}$, Rahman $\mathrm{T}^{3}$ \\ ${ }^{I}$ Department of Neurology, Shaheed Suhrawardy Medical College, Dhaka, Bangladesh \\ ${ }^{2}$ Department of Neurology, Shaheed Suhrawardy Medical College, Dhaka, Bangladesh \\ ${ }^{3}$ Department of Neurosurgery, Shaheed Suhrawardy Medical College, Dhaka, Bangladesh \\ ${ }^{4}$ Department of Neurology, Chittagong Medical College, Chittagong, Bangladesh
}

*Corresponding Author: Priyatosh Chandra Das, Associate Professor, Department of Neurology,

Shaheed Suhrawardy Medical College Dhaka, Bangladesh, Email: priyatoshdascmc26@yahoo.com

\begin{abstract}
Background: A high proportion of patients suffering an acute stressful condition such as stroke or myocardial infarction may develop hyperglycemia even in the absence of a pre-existing diagnosis of diabetes. The study evaluates the effect of hyperglycemia in the severity and outcome during the acute phase of stroke.
\end{abstract}

Methods: This was a descriptive cross-sectional study. Baseline variables (eg: age, sex, smoking, hypertension, diabetes OHA/insulin) and outcome measures (mortaily, disability) were statistically analysed and compared with a control group 50 patients of acute ischemic stroke without admission hyperglycemia.

Result: The base line characteristics of the two patients groups were comparable. The $1^{\text {st }}$ week mortality was $16 \%$ in case group and $2 \%$ in the control group. The 30 days mortality in the case control grop was $28 \%$ and $12 \%$ respectively, $58.33 \%$ were disabled \& dependent in the hyperglycemia group, in comparison to $36.36 \%$ subjects in the control group.

Conclusion: Admission hyperglycemia seems worsen the outcome and functional disability during the acute phase of Ischemic stroke. Admission glucose level is an important risk factor and should be immediately treated to reduce morbitidity \& mortality in acute Ischemic stroke cases.

Keywords: Stroke, Hyperglycemia, Cerebral Ischemia, cerebro vascular Injury disability.

\section{INTRODUCTION}

Stroke is one of the leading causes of death and disability worldwide and more so in underdeveloped countries like Bangladesh where health support system including rehabilitation is not expectedly available. At least $50 \%$ of the neurological disorder in a general hospital is of stroke. World Health Organizasion (WHO) defined Stroke as rapidly developiong clinical signs of focal or global disturbance of cerebral function, with symptoms lasting 24 hours or longer or leading to death, with no apparent cause other than vascular origin $^{1}$.

Most of the stroke is due to cerebral infarction $(80 \%)$ the rest is due to haemorrhage. Modifiable risk factors for stroke include hypertension, diabetes, a trial fibrillation, dislipidemia, smoking and alcohol abuse. About one third of patients with acute stroke and no prior diagnosis of diabetes have hyperglycemia during acute phase of stroke $e^{2,9,10}$ and is associated with worse neurological outcome and increased stroke mortality ${ }^{11,12,13}$. Weather this is an acute stress response or a reflexion of underlying diabeties is controversial ${ }^{2,14,15,16}$.

Hyperglycemia has been reported to worsen the tolerance of the brain to is chemia ${ }^{(3,4)}$. Both acute and chronic hyperglycaemia are associated with increased oedema and infarct size $e^{5,7,8,17}$ and with reduced cerebral blood flow and cerebrovascular reserve ${ }^{6,18}$. The early recognition of disorder of glucose metabolism in stroke patients is important because hyperglycemia during the acute phase worsens the outcome probably by reducing the salvage of penumbral tissue medicated by high lactate level of brain tissue $\mathrm{e}^{5,19,20,21}$. 
Hyperglycemia in animal models has been shown to exacerbate acutischemic conditions by stimulating vascular inflammation, increasing blood-brain barrier permeability, impairing cellular metabolism, and promoting tissue acidosis $22,25,26,27$. In models in which the ischemic brain tissue is reperfused, hyperglycemia proves to increase the size of the infarct progressively ${ }^{28,29}$, whether in models without reperfusion, it happened to shrink or do nothing ${ }^{30,31}$.

Despite of these observations, the relationship between glucose level and outcome after stroke in diabetic and non diabetic patients has not been well characterised and those studies that have examined this relationship have reported confliciting results ${ }^{6,22,23,24,31}$. The present study is carried out to find out the relationship of admission hyperglycemia and its outcome in terms of mortality and morbidity after an acute ischemic stroke.

\section{METHODS}

Study Design: this study was designed as a descriptive cross- sectional study.

\section{Study setting \& population}

This study was done among patients admitted in Shaheed Suhrawardy Medical College Hospital between July 2012 to June 2013.Tomographic (CT) diagnosis of ischemic stroke with admission hyperglycemia (RBS $>8 \mathrm{mmol} / \mathrm{L}$ ) were included in the study.

Patternts with intracerebral haemorrhage, subarachnoid haemorrhage transient Ischemic attack and with non-stroke cause of focal neurological deficit eg.brain tumour were excluded from the study. Those patients with

Table1. Age distribution of study subjects ( $n=100$, control 50, case 50)

\begin{tabular}{|l|l|l|l|}
\hline \multirow{2}{*}{ Age group } & \multicolumn{2}{|c|}{ Control No. (\%) } & \multirow{2}{*}{ p value } \\
\cline { 2 - 3 } & \multicolumn{1}{|c|}{ Case No. (\%) } & \multicolumn{1}{|c|}{} \\
\hline $21-30$ & $1(2)$ & $2(4)$ & \\
$41-40$ & $9(1)$ & $0(0)$ & \\
$51-60$ & $11(22)$ & $6(12)$ & \\
$61-70$ & $19(38)$ & $21(42)$ & \\
$71-80$ & $7(14)$ & $14(28)$ & \\
$81-90$ & $1(2)$ & $7(14)$ & \\
\hline Total & $50(100)$ & $0(0)$ & \\
\hline Range & $21-90$ & $50(100)$ & \\
\hline Mean + SD (years) & $60.80+12.37$ & $21-90$ & \\
\hline
\end{tabular}

Chi square test was done, which was not significant $(P>0.05)$

Out of 50 cases $31(62 \%)$ were male and $19(38 \%)$ were female given a male to female ratio of 1.6:1. Among the 50 controls 32 (64\%) were male and $18(36 \%)$ were gemale giving a male to female ratio of 1.7:1. Analysis revealed associated co-morbidity like myocardial in fraction, a trial fibrailation, cancer also not included in the study.

100 patients were selected by purposive type of non probability saemping technique.

A random blood glucose was measured on admission (or within 24 hours of admission) to define admission hyperglycemia (RBS> $8 \mathrm{mmol} / \mathrm{L}$ ). Among them 50 patients who fulfilled the inclusion criteria were selected as case group and another 50 patients with RBS < $8 \mathrm{mmol} / \mathrm{L}$ were selected for comparison.

Data were collected by taking medical history. Clinical evaluation and laboratory investigations were recorded in a structured data sheet.

The samples under study were examined for assessment and followed up during admission, one week after admission and after one month of discharge from the hospital. Outcome was assessed in terms of fatality and functional recovery after 30 days adjusting age, stroke severity and comorbid conditions parameters used for assessment of stroke severity and outcome were the NIHSS (National Institute of Health stroke scale) and the modified Rankin Scale (MRS) ${ }^{7}$. Data were analyzed by statistical package for social science (SPSS) programme.

\section{RESULT}

The mean age of the control was $60.10 \pm 11.35$ years and that of cases was $60.80( \pm 12.37)$ years. Majority of the patients belonged to the $6^{\text {th }} \& 7^{\text {th }}$ decade of life. Analysis found no statistically significant difference between the mean age of the control and the cases $(\mathrm{P}>0.05)$. This is shown in Table 1 that no statistically significant different was found between the sex distribution of the subjects of two groups $(\mathrm{P}>0.05)$. This is shown in Table 2 
Association between Admission Hyperglycemia and Outcome in Acute Ischemic Stroke Cases: an Observational Study

Table2. Sex distribution of study subjects ( $n=100$, Control 50, case 50)

\begin{tabular}{|l|l|l|l|}
\hline \multirow{2}{*}{ Sex } & \multicolumn{2}{|c|}{ Study Subjects } & \multirow{2}{*}{ p value } \\
\cline { 2 - 3 } & \multicolumn{1}{|c|}{ Case No. (\%) } & \multicolumn{1}{|}{} \\
\hline Male & $31(62)$ & $32(64)$ & \\
Female & $19(38)$ & $18(36)$ & \multirow{2}{*}{0.836} \\
\hline Total & $50(100)$ & $50(100)$ & $1.7: 1$ \\
\hline
\end{tabular}

Chi square test was done, which was not significant $(P>0.05)$

Observation shows $30(60 \%)$ subjects of case group and 34(68\%) subjects of control group have the history of hypertension before ischemic stroke. Analysis revealed no statistically

significant difference between the case group and control group regarding previous history of hypertension $(\mathrm{P}>0.05)$. This is shown in Table 3

Table3. Comparison presence of hypertension between case and control group ( $n=100$, Control 50, case 50)

\begin{tabular}{|l|l|l|l|l|}
\hline \multicolumn{1}{|c|}{ Study Subjects } & \multicolumn{3}{|c|}{ Hypertension } & p value \\
\cline { 2 - 5 } & \multicolumn{1}{|c|}{ Present No. (\%) } & \multicolumn{1}{|c|}{ Absent No. (\%) } & No. (\%) & \\
\hline Case & $32(60)$ & $20(40)$ & $50(100)$ & \\
Control & $34(64)$ & $16(32)$ & $50(100)$ & 0.405 \\
\hline
\end{tabular}

Chi square test was done, which was not significant $(P>0.05)$

The mean blood glucose level in case group was $11 \pm 2.58 \mathrm{mmol} / \mathrm{L}$ (Mean $\pm \mathrm{SD})$ and that of control group was $5.8 \pm 0 . \overline{7} 2 \mathrm{mmol} / \mathrm{L}$ (Mean +SD). Unpaired " $\mathrm{t}$ " test showed that there was

Table4. Comparison of blood glucose level between case and control group ( $n=100$, Control 50, case 50)

\begin{tabular}{|c|c|c|c|c|c|}
\hline \multirow[t]{2}{*}{ Admission RBS } & \multicolumn{2}{|c|}{$\begin{array}{c}\text { Case group } \\
\text { Range }(8-20) \\
\end{array}$} & \multicolumn{2}{|c|}{$\begin{array}{c}\text { Control group } \\
\text { Range }(4.3-7.6)\end{array}$} & \multirow[t]{2}{*}{$P$ value } \\
\hline & Number & Mean + SD & Number & Mean \pm SD & \\
\hline $4-4.9$ & & \multirow{16}{*}{$11 \pm 2.58$} & 6 & \multirow{16}{*}{$5.8 \pm 0.72$} & \multirow{16}{*}{0.001} \\
\hline $5-5.9$ & & & 17 & & \\
\hline $6-6.9$ & & & 25 & & \\
\hline $7-8$ & & & 2 & & \\
\hline $8-8.9$ & 11 & & & & \\
\hline $9-9.9$ & 10 & & & & \\
\hline $10-10.9$ & 7 & & & & \\
\hline $11-11.9$ & 10 & & & & \\
\hline $12-12.9$ & 4 & & & & \\
\hline $13-13.9$ & 2 & & & & \\
\hline $14-14.9$ & 3 & & & & \\
\hline $15-15.9$ & 1 & & & & \\
\hline $16-16.9$ & 0 & & & & \\
\hline $17-17.9$ & 0 & & & & \\
\hline $18-18.9$ & 0 & & & & \\
\hline $19-20$ & 2 & & & & \\
\hline Total & 50 & & 50 & & \\
\hline
\end{tabular}

Unpaired " $t$ " test was done, which was significant $(P<0.01)$

In the case group $8(16 \%)$ subjects died in $1^{\text {st }}$ week in the case group and $1(2 \%)$ subjects died in $1^{\text {st }}$ week in control group. Statistical analysis

showed that there is significance in mortality during first week between the case and control group $(\mathrm{P}<0.05)$. This is shown in Table 5

Table5. Comparison of mortality in 1st week between case and control group ( $n=100$, Control 50, case 50)

\begin{tabular}{|l|l|l|l|l|}
\hline \multirow{2}{*}{ Study Subjects } & \multicolumn{2}{|c|}{ Death in 1 $\mathbf{1}^{\text {st }}$ week } & \multirow{2}{*}{ p value } \\
\cline { 2 - 4 } & \multicolumn{1}{|c|}{ Yes No. $(\%)$} & \multicolumn{1}{|c|}{ No No. (\%) } & \\
\hline Case & $8(16)$ & $42(84)$ & $50(100)$ & \multirow{2}{*}{0.036} \\
Control & $1(2)$ & $49(98)$ & $50(100)$ & \\
\hline Total & 9 & 91 & -100 & \\
\hline
\end{tabular}

Chi square test was done, which was significant $(P<0.05)$ 
In another observation 14 (28\%) subjects of case group and 6(12\%) subjects of control groups died after 30 days of ischemic stroke. Statistical analysios showed that there is significant

Table6. Comparison of mortality in 30 days between case and control group ( $n=100$, Control 50, case 50)

\begin{tabular}{|l|l|l|l|l|}
\hline \multirow{2}{*}{ Study Subjects } & \multicolumn{3}{|c|}{ Death in 30 days } & \multirow{2}{*}{ p value } \\
\cline { 2 - 4 } Case & \multicolumn{1}{|c|}{ Yes No. (\%) } & \multicolumn{1}{|c|}{ No. $(\%)$} & \multicolumn{2}{|c}{} \\
Control & $14(28)$ & $36(72)$ & 50 & \multirow{2}{*}{0.046} \\
\hline Total & $6(12)$ & $44(88)$ & 50 & \\
\hline
\end{tabular}

Chi square test was done, which was significant $(P<0.05)$

Table 7 shows 21(58.33) subjects of case group and $16(36.36 \%)$ subjects of control group has become dependent after 30 days of ischemic stroke. On the other hand $15(41.67 \%)$ subjects in the case group and 28(63.64\%) subjects in the

Table7. Comparison of disability among survivors after $1^{\text {st }}$ week and 30 days case and control group $(n=100)$

\begin{tabular}{|c|c|c|c|c|c|c|}
\hline \multirow{3}{*}{$\begin{array}{l}\text { Study } \\
\text { Subjects }\end{array}$} & \multicolumn{5}{|c|}{ Death in 30 days } & \multirow{3}{*}{ p value } \\
\hline & \multirow{2}{*}{$\begin{array}{l}\text { On admission } \\
\text { No }(\%)\end{array}$} & \multirow{2}{*}{$\begin{array}{|lc|}\text { After } & 1^{\text {st }} \\
\text { week } & \text { No. } \\
(\%) & \\
\end{array}$} & \multicolumn{3}{|c|}{ After 30 days } & \\
\hline & & & $\begin{array}{c}\text { Total } \\
\text { Disability }\end{array}$ & $\begin{array}{l}\text { Dependent No. } \\
(\%)\end{array}$ & \begin{tabular}{|l} 
Independent No \\
$(\%)$
\end{tabular} & \\
\hline $\begin{array}{l}\text { Case } \\
\text { Control }\end{array}$ & $\begin{array}{l}50(100) \\
50(100)\end{array}$ & $\begin{array}{l}42(84 \%) \\
44(98 \%)\end{array}$ & $\begin{array}{l}36(72 \%) \\
44(88 \%)\end{array}$ & $\begin{array}{l}21(58.36) \\
16(36.66)\end{array}$ & $\begin{array}{l}15(41.67) \\
28(63.64)\end{array}$ & \multirow{2}{*}{0.049} \\
\hline Total & 100 & 90 & 80 & 37 & 43 & \\
\hline
\end{tabular}

Chi square test was done, which was significant $(P<0.05)$

Table 8 shows that $8(40 \%)$ subjects who were treated for hyperglycemia became dependent whereas $13(81.25 \%)$ subject who were not treated for hyperglycemia became dependent.

Table8. Comparison of disability among survivors after 30 days between treated and non treated group of hyperglycemia $(n=36$, treated 20 , non treated 16$)$

\begin{tabular}{|l|l|l|l|l|}
\hline \multirow{2}{*}{ Study Subjects } & Disability after 30 days & Total & \multirow{2}{*}{ p value } \\
\cline { 2 - 4 } Treated & Dependent No. $(\%)$ & Independent No. $(\%)$ & No (\%) & \multirow{2}{*}{0.031} \\
Non treated & $8(40)$ & $12(60)$ & $20(100)$ & \\
\hline Total & $13(81.25)$ & $3(18.75)$ & 36 & \\
\hline
\end{tabular}

Chi square test was done, which was significant $(P<0.05)$

\section{DISCUSSION}

The present study was carried out to find out the effect of admission hyperglycemia in patients with ischemic stroke irrespective of the cause of hyperglycemia. The study done to find out the assocaition of sociodemographic factors like age, sex, socioeconomic status, personal habit like smoking, family history of stroke and other diseases like hypertension as risk factor in the development of ischemic stroke.

One hundred subjects with ischemic stroke were included in this study of which 50 subjects with ischemic stroke were in the case group with
Statistical analysis shows significant difference between the treated and none treated group of admission hyperglycemia. admission hyperglycemia (RBS > 8mmol/L) during admission.

Regarding sex distribution, both the controls and cases were well matched with no significant statistical difference $(\mathrm{P}>0.05)$

The study also showed that $26 \%$ of control group and $28 \%$ of case group had the family history of stroke. Statistical analysis found no significant difference between the two group regarding family history of stroke $(\mathrm{P}>0.05)$.

In the present study, $60 \%$ of subjects in the cese group and $68 \%$ of subjects in the control group were hypertensive. No statistically singnificant 
difference was noted between the two groups $(\mathrm{P}>0.05)$.

Hyperglycemia is frequently seen in the acute phase of ischemic stroke affecting up to $20 \%$ to $50 \%$ of patients at presentation.

In the present study, the mean admission blood glucose level was $11 \pm 2.58 \mathrm{mmol} / \mathrm{L}($ mean $\pm \mathrm{SD})$ in the case group and $5.8 \pm 0.72 \mathrm{mmol} / \mathrm{L}$ $($ mean + SD) in the control group with a cumulative mean value of $8.4 \pm 1.65 \mathrm{mmol} / \mathrm{L}$ (mean \pm SD). Statistical analysis revealed significant difference between admission blood glucose level in the case and control group $(\mathrm{P}<0.05)$. This result coincides with the study done by L. S. Williams et al. in which mean admission blood glucose level in the control group was $98 \pm 0.8 \mathrm{mg} / \mathrm{dl}(5.4 \pm 0.04 \mathrm{mmol} / \mathrm{L})$ and that in case group was $224 \pm 5.7 \mathrm{mg} / \mathrm{dl}$ $(12.4 \pm 0.32 \mathrm{mmol} / \mathrm{L})$. $\mathrm{P}$ value was less than 0.0001 doing chi squared test ${ }^{5,8}$.

Admission hyperglycemia was associated with higher mortality rate than was euglycemia. In this study, $16 \%$ patients of hyperglycemia group died in the first week in comparison with only $2 \%$ in the euglycemic group. Which is statistically significant $(\mathrm{P}<0.05)$. Death in $1^{\text {st }}$ week was more in 61-70 years age group (6\%) in the cases in comparison to $(2 \%)$ in the controls of the same age group.

The higher rate of death in the present study may be due to lack of early reperfusion and thrombolytic therapy and inadequate supportice treatment facilities in our hospital set-up.

Regarding mortality after 30 days of ischemic stroke, the hyperglycemic group showed mortality rate $28 \%$ in comparison with $12 \%$ in the euglycemic group. This indicates a 2.3 fold increase in mortality among the patients with admission hyperglycemia which is also statistically significant $(\mathrm{P}<0.05)$. This gets consistent with the similar study of Williams LS et al, too, where the rates were $10 \%$ and $5 \%$ respectively ${ }^{5}$ and with the study of Bruno A. et al, where the odds of good outcome decreased sharply with rises in blood glucose level from 50 to $150 \mathrm{mg} / \mathrm{dl}^{32}$.

In this study, $58.33 \%$ survivors of the case group and $36.3 \%$ of the control group were severely disabled after 30 days of ischemic stroke. The remainder $41.67 \%$ of patients of the case group and $63.64 \%$ of the control group become functionally independent despite some residual disability $(\mathrm{P}<0.05)$.

\section{CONCLUSION}

The study revealed that there is an association between admission hyperglycemia and poor outcome after acute ischemic stroke. Admission hyperglycemia worsens the outcome and functional disability during the phase of ischemic stroke. The study also suggests that admission glucose level is an important risk factor and should be immediately treated to reduce morbidity and mortality in acute ischemic stroke.

\section{REFERENCES}

[1] World Health organization (WHO) task force recommendation on stroke prevention, diagnosis and therapy. Report of the WHO task force on stroke and other cerebro vascular disorders. Stroke, 1989; 20: 1407-31

[2] Vancheri F, Curcio M, Burgio A, Salvaggio S, Gruttadauria G, Lunetta MC, Dovico R, Alletto M. Imparied glucose metabolism in patients with acute stroke and no previous diagnosis of diabetes mellitus. Q.J. Med 2005; 98 (2): 871-8

[3] Islam N, Aftabuddin M, Moriwaki A. Blood glucose and ischemic brain damage: effect of hypoglycaemia on incomplete Ischemia induced brain damage. Bangladesh Journal of Neuroscience 1997; 9:8

[4] Sieber FE, Smith DS, Traystman RJ. Wollman H. Glucose : A re-evaluation of its intra operative use, anaesthesiology 1987; 67:72

[5] Williams LS. Rotich J, Qi R, Fineberg N, Espay A. Bruno A, Fineberg SE, Tierney WR. Effect of admission hyperglycemia an mortality and costs in acute Ischemic stroke. Neurology 2002; 59: $67-71$

[6] Lees KR, Walters MR, Acute Stroke and diabetes. Acute Stroke unit and cerebrovascular clinic. Western Infirmary Glasgow, UK 2005; $1: 9-14$

[7] http//www.medalreg.com/qhe/medal/ch37/3716/37-16-02-ver9.Php3

[8] Bell DSH. Stroke in the diabetic patient. Diabetes Care 1994; 17:213-19.

[9] Bravata DM, Kim N, Concato J, Brass LM. Hyperglycaemia in patients with acute ischaemic stroke: how often do we screen for undiagnosed diabetes? Q J Med 2003; 96:4917.

[10] Lindsberg PJ, Roine RO. Hyperglycemia in acute stroke. Stroke 2004; 35:363-4.

[11] Weir CJ, Murray GD, Dyker AG, Lees KR. Is hyperglycaemia an independent predictor of poor outcome after acute stroke? Results of a long term follow up study. Br Med J 1997; 314:1303-6.

[12] Capes SE, Hunt D, Malmberg K, Pathak P, Gerstein HC. Stress hyperglycemia and 
prognosis of stroke in nondiabetic and diabetic patients. A systematic overview. Stroke 2001; 32:2426-32.

[13] Baird TA, Parsons MW, Phanh T, Butcher KS, Desmond PM, Tress BM, Colman PG, Chambers BR, Davis SM. Persistent poststroke hyperglycemia is independently associated with infarct expansion and worse clinical outcome. Stroke 2003; 34:2208-14.

[14] O’Neill PA, Davies I, Fullerton KJ, Bennett D. Stress hormone and blood response following acute stroke in the elderly. Stroke 1991; 22:842-7.

[15] Kooten van F, Hoogerbrugge N, Naarding P, Koudstaal PJ. Hyperglycemia in the acute phase of stroke is not caused by stress. Stroke 1993; 24:1129-32.

[16] Scott JF, Gray CS, O'Connell JE, Alberti KGMM. Glucose and insulin therapy in acute stroke; why delay further? Q J Med 1998; 91:511-15.

[17] Helgason CM. Blood glucose and stroke. Stroke 1988;19:1049-53.

[18] De Chiara S, Mancini M, Vaccaro O, Riccardi G, Ferrara LA,Gallotta G, et al. Cerebrovascular reactivity by transcranial Doppler ultrasonography in insulin-dependent diabetic patients. Cerebrovasc Dis 1993; 3:111-5.

[19] Rehncrona S, Rosen I, Siesjo BK. Brain lactic acidosis and ischemic dam- age. I: Biochemistry and neurophysiology. J Cereb Blood Flow Metab 1981; 1:297-311.

[20] Chew W, Kucharczyk J, Moseley M, Derugin $\mathrm{N}$, Norman D. Hyperglycemia augments ischemic brain injury: in vivo MR imaging/ spectroscopic study with nicardipine in cats with occluded middle cerebral arteries. Am J Neuroradiol 1991; 12:603-9.

[21] Pulsinelli WA, Waldman S, Rawlinson D, Plum F. Moderate hyperglycemia augments ischemic brain damage: a neuropathologic study in the rat. Neurology 1982; 32:1239-46.

[22] Woo J, Lam CWK, Kay R, Wong AHY, Teoh $\mathrm{R}$, Nicholls MG. The influence of hyperglycemia and diabetes mellitus on immediate and 3-month morbidity and mortality after acute stroke. Arch Neurol 1990;47:1174-7
[23] Adams HP Jr, Olinger CP, Marler JR, Biller J, Brott TG, Barsan WG, Banwart K. Comparison of admission serum glucose concentration with neurologic outcome in acute cerebral infarction. A study in patients given naloxone. Stroke. 1988 Apr; 19(4):455-8.

[24] Matchar DB, Divine GW, Heyman A, Feussner JR. The influence of hyperglycemia on outcome of cerebral infarction. Ann Intern Med. 1992 Sep 15; 117(6):449-56.

[25] Widmer H, Abiko H, Faden AI, James TL, Weinstein PR.Effects of hyperglycemia on the time course of change in energy metabolism and $\mathrm{pH}$ during global cerebral ischemia and reperfusion in rats. J Cereb Blood Flow Metab. 1992; 12:456-68.

[26] Dietrich WD, Alonso O, Busto R. Moderate hyperglycemia worsens acute blood-brain barrier injury after forebrain ischemia in rats. Stroke. 1993; 24:111-6.

[27] Folbergrova J, Memezawa H, Smith ML, Siesjo BK. Focal and perifocal changes in tissue energy state during middle cerebral artery occlusion in normoand hyperglycemic rats. $\mathbf{J}$ Cereb Blood Flow Metab. 1992; 12:25-33.

[28] Venables G, Miller SA, Gibson G, Hardy J, Strong A. the effects of hyperglycemia on changes during reperfusion following focal cerebral ischaemia in the cat. $J$ Neurol Neurosurg Psychiatry 1985;48:663-669

[29] De Courten- Myers GM, Kleinholz M, Wagner KR, Myers RE, Fatal strokes in hyperglycemic cats. Stroke 1989; 20:1707-1715.

[30] Ginsberg MD, Prado R, Dietrich WD, Busto R, Watson BD. Hyperglycemia reduces the extent of cerebral infarction in rats. Stroke 1987; 18:570-574

[31] Nedergaard M, Diemer N. Focal ischemia of the rat brain, with special reference to the influence of plasma glucose concentration. Acta Neuropathol 1987; 73:131-137.

[32] Bruno A, Biller J, Adams HP Jr, Clarke WR, Woolson RF, Williams LS, Hansen MD. Acute blood glucose level and outcome from ischemic stroke. Trial of ORG 10172 in Acute Stroke Treatment (TOAST) Investigators. Neurology. 1999 Jan 15; 52(2):280-4.

Citation: Priyatosh Chandra Das, Islam M M, Sarkar S, Rahman T. Association between Admission Hyperglycemia and Outcome in Acute Ischemic Stroke Cases: an Observational Study. ARC Journal of Cancer Science 2017; 3(1):18-23. DOI: http://dx.doi.org/10.20431/2455-6009.0301004

Copyright: () 2017 Authors. This is an open-access article distributed under the terms of the Creative Commons Attribution License, which permits unrestricted use, distribution, and reproduction in any medium, provided the original author and source are credited. 